\title{
Millet irrigation with treated wastewater: Gas exchange response and nutrient accumulation
}

\section{Irrigação de milheto com água residuária tratada: Resposta de trocas gasosas e acúmulo de nutriente}

\author{
Matheus Mendes Reis ${ }^{1 *}\left(\mathbb{D}\right.$, Ariovaldo José da Silva ${ }^{1} \mathbb{D}$, Leonardo David Tuffi Santos ${ }^{2} \mathbb{D}$, \\ Érika Manuela Gonçalves Lopes ${ }^{2}$, Rodrigo Eduardo Barros ${ }^{2}$, Luan Mateus Silva Donato²
}

\author{
'Universidade Estadual de Campinas/UNICAMP, Faculdade de Engenharia Agrícola/ FEAGRI, Campinas, SP, Brasil \\ ${ }^{2}$ Universidade Federal de Minas Gerais/UFMG, Instituto de Ciências Agrárias/ICA, Montes Claros, MG, Brasil \\ *Corresponding author: matheussmendes@hotmail.com \\ Received in October 10, 2019 and approved in November 11, 2019
}

\begin{abstract}
Wastewater can be considered an excellent nutritional and water source for cultivated plants. However, the presence of high concentrations of salts and toxic compounds can negatively affect crops. The effect of irrigation with different concentrations of treated wastewater on the accumulation of nutrients and gas exchange aspects of millet (Pennisetum g/aucum (L.) R. Br.) grown in clay soil and sandy loam soil was analyzed. This study was conducted in a greenhouse $\left(16^{\circ} 40^{\prime} 57,50^{\prime \prime} \mathrm{S} ; 43^{\circ} 50^{\prime} 26,07^{\prime \prime} \mathrm{O} ; 650 \mathrm{~m}\right)$ in a 5 × 2 factorial design, consisting of five levels of concentration of treated wastewater $(0,25,50,75$, and 100\%), combined with two types of soil (clay and sandy loam). The experiment was designed in randomized blocks with four replicates. The increase in treated wastewater concentration in irrigation water applied to clay soil and sandy loam soil favored the increase of net photosynthesis, transpiration rate, stomatal conductance, leaf chlorophyll content and accumulation of macro- and micronutrients in millet plants. Millet plants grown in clay soil showed an average increase of $23 \%$ in gas exchange capacity and $71 \%$ in accumulation of macro- and micronutrients, when compared with treatments in sandy loam soil. Therefore, treated wastewater contributes to the increase in gas exchange capacity and greater accumulation of nutrients in millet plants, which represents an alternative for reduced demand for fresh water and use of chemical fertilizers.
\end{abstract}

Index terms: Pennisetum glaucum; water reuse; nutrient absorption; photosynthesis.

\begin{abstract}
RESUMO
As águas residuárias podem ser consideradas como uma fonte hídrica e nutricional excelente para as plantas cultivadas. Porém, a presença de altas concentrações de sais e de compostos tóxicos pode afetar negativamente as plantações. Avaliou-se o efeito da irrigação com diferentes concentrações de água residuária tratada sobre o acumulo de nutrientes e os aspectos fisiológicos do milheto (Pennisetum glaucum (L.) R. Br.) cultivado em solo argiloso e franco arenoso. O estudo foi conduzido em casa de vegetação (16 40'57,50" S; 4350'26,07" $0 ; 650 \mathrm{~m}$ ) em esquema fatorial $5 \times 2$, consistindo de cinco níveis de concentração da água residuária tratada (0, 25, 50, 75 e 100\%), combinado com dois tipos de solo (argiloso e franco arenoso). O delineamento estatístico do experimento foi em blocos casualizados com quatro repetições. $O$ aumento na concentração de água residuária tratada na água de irrigação aplicada em solo argiloso e franco arenoso favoreceu o aumento da fotossíntese líquida, taxa de transpiração, condutância estomática, teor de clorofila foliar e acumulo de macro e micronutrientes nas plantas de milheto. Plantas de milheto cultivadas em solo argiloso apresentam aumento médio de $23 \%$ na capacidade de troca de gases e de $71 \%$ no acumulo de macro e micronutrientes, quando comparado com os tratamentos em solo franco arenoso. Portanto, a água residuária tratada contribui para o aumento da capacidade de troca de gases e maior acumulo de nutrientes em plantas de milheto, o que representa uma alternativa para a redução da demanda por água doce e uso de fertilizantes químicos.
\end{abstract}

Termos para indexação: Pennisetum glaucum; reuso de água; absorção de nutrientes; fotossíntese.

\section{INTRODUCTION}

Lower demand for fresh water, nutrient recycling and reduced in the discharge of pollutants in water bodies are potential benefits of the use of treated wastewater (TW) in the irrigation of agricultural crops (Hanjra et al., 2012). Studies relate TW irrigation to increase in biomass and photosynthetic capacity; improvement in mineral status; and reduction in fertilizer application rates in several crops (Ben Hassena et al., 2018; Demir; Sahin, 2017; Tekaya et al., 2016), including pastures (Dube et al., 2018). Furthermore, Ali-Shtayeh et al. (2018) observed 
that the use of TW in irrigation does not affect the yield and chemical composition of crops used in the production of essential oils.

However, the use of wastewater in irrigation may present risks that need to be observed, such as soil salinization and sodification (Bedbabis et al., 2015), nutrient excess (Kalavrouziotis et al., 2008), and contamination by microorganisms (Bernstein, 2011; Obayomi et al., 2019), heavy metals (Meng et al., 2016; Farahat; Linderholm, 2015) and pharmaceuticals and personal care products (PPCPs) (Thelusmond; Strathmann; Cupples, 2019). These risks may negatively affect human health, the environment and agricultural production.

Despite these risks, it is suggested that good agricultural practices performed with planning and management can reduce undesirable consequences (Who, 2006). The acceptable quality of wastewater for irrigation depends on the crop to be irrigated, soil conditions and the water distribution system adopted (Ayers; Westcot, 1999). Thus, measures to mitigate the negative impacts of the use of wastewater in agricultural irrigation are essential for the good yield of crops and reduction in environmental risks. An option to mitigate such impacts is to use wastewater with fresh water, if available, to reduce the application rate of chemical and biological constituents in irrigated crops (Ayers; Westcot, 1999; Malash; Flowers; Ragab, 2005; Yu et al., 2012).

Soils can show great variability in their physical, chemical and hydraulic properties, depending on their textural and structural characteristics, and this variability has different effects on plant growth and development (Paudel et al., 2017, 2016). Wastewater contains high concentrations of saline components and organic and inorganic suspended particles compared to freshwater, which may modify soil texture and structure and soil water retention and infiltration (Paudel et al., 2017, 2016). Therefore, understanding the effects of wastewater on plant physiology and nutritional composition, at least in the short term, could contribute to the sustainable use of wastewater in agricultural irrigation. However, the effects of wastewater on plant growth and development will depend on the textural and structural characteristics of the soil (Dube et al., 2018; Panta et al., 2016; Paudel et al., 2016; Zhang et al., 2016).

Millet (Pennisetum glaucum (L.) R. Br.) occupies over 30 million hectares in 30 countries, located in Asia, Africa, the Americas and Australia, and is an important cereal crop for arid and semi-arid regions (Jukanti et al., 2016) (regions where freshwater scarcity is most common). Besides, compared to other cereal crops such as rice, wheat, corn, and sorghum, it has a high tolerance to abiotic stresses such as drought, salinity, high temperatures and nutrient deficiency in the soil (Dudhate et al., 2018; Jukanti et al., 2016).

This study aimed to evaluate the effect of the irrigation of clay and sandy loam soil with different TW concentrations on the accumulation of nutrients, leaf chlorophyll content and photosynthetic capacity of millet plants (Pennisetum glaucum).

\section{MATERIAL AND METHODS}

The experiment was carried out, in a greenhouse at the Federal University of Minas Gerais, in the city of Montes Claros, MG, Brazil (16²0’57,50” S; 4350’26,07” $\mathrm{O} ; 650 \mathrm{~m}$ ). The climate of the region is classified, according to Köppen, as Aw, tropical climate with a dry winter.

The experiment was designed in randomized blocks with four replicates and a $5 \times 2$ factorial design. The treatments corresponded to five levels of concentration of treated wastewater (TW) $(0,25,50$, 75 , and $100 \%$ ) applied through irrigation combined with two soil types (clay soil (CS) and sandy loam soil (SLS)). The levels of TW concentration $(0,25,50,75$, and $100 \%$ ) correspond to: (i) distilled water (control); (ii) $25 \% \mathrm{TW}+75 \%$ distilled water; (iii) $50 \% \mathrm{TW}+50 \%$ distilled water; (iv) $75 \% \mathrm{TW}+25 \%$ distilled water; and (v) $100 \% \mathrm{TW}$, respectively.

The TW used in the irrigation was obtained from the wastewater treatment plant (ETE) from Montes Claros, MG, where the collected sewage is subjected to a preliminary treatment for the removal of coarse materials and sand. Then, the sewage is subjected to a secondary biological treatment using anaerobic reactors. In the next step, the wastewater is transferred to biological aerobic filters. Decantation is the last treatment. After the collection, TW was sent to the laboratory for chemical characterization (Table 1), according to (APHA, 2012).

The soils used in the experiments were collected in the layer from 0 to $0.30 \mathrm{~m}$ deep in a Red Latosol (RL) and in a Haplic Cambisol (HC), classified according to Embrapa (2013). The clay soil, classified as $\mathrm{CH}$, was obtained from a eucalyptus cultivation region $\left(16^{\circ} 40^{\prime} 22,23^{\prime \prime} \mathrm{S}\right.$; $43^{\circ} 50^{\prime} 29,41^{\prime \prime} \mathrm{O}$ ), and the sandy loam soil, classified as $\mathrm{LV}$, from a pasture $\left(16^{\circ} 55^{\prime} 16,34^{\prime \prime} \mathrm{S}\right.$; 43 $\left.{ }^{\circ} 57^{\prime} 60,00^{\prime \prime} \mathrm{O}\right)$. Both soils were broken up, air-dried and sieved ( $2 \mathrm{~mm}$ sieve), before being sent to the laboratory for physical and chemical characterization (Table 2). 
Table 1: Concentration of chemical elements present in the treated wastewater used in this experiment.

\begin{tabular}{|c|c|c|c|c|c|c|}
\hline & \multirow{2}{*}{ Units } & \multirow{2}{*}{ TW } & \multicolumn{3}{|c|}{ Degree of restriction on use for irrigation ${ }^{a}$} & \multirow{2}{*}{$\begin{array}{l}\text { Maximum concentration } \\
\text { for irrigation }{ }^{a}\end{array}$} \\
\hline & & & None & Slight to Moderate & Severe & \\
\hline $\mathrm{N}$ & $\mathrm{mg} \mathrm{L}^{-1}$ & 413.6 & $<5$ & 5 to 30 & $>30$ & - \\
\hline $\mathrm{P}$ & $\mathrm{mg} \mathrm{L}^{-1}$ & 5.1 & - & - & - & - \\
\hline $\mathrm{K}$ & $\mathrm{mg} \mathrm{L}^{-1}$ & 0 & - & - & - & - \\
\hline $\mathrm{Ca}$ & $\mathrm{mg} \mathrm{L}^{-1}$ & 50.5 & - & - & - & - \\
\hline Mg & $\mathrm{mg} \mathrm{L}^{-1}$ & 7.0 & - & - & - & - \\
\hline $\mathrm{S}$ & $\mathrm{mg} \mathrm{L}^{-1}$ & 15.6 & - & - & - & - \\
\hline $\mathrm{Zn}$ & $\mathrm{mg} \mathrm{L}^{-1}$ & 0.6 & - & - & - & 2 \\
\hline $\mathrm{Fe}$ & $\mathrm{mg} \mathrm{L}^{-1}$ & 1.3 & $<0.1^{\mathrm{b}}$ & 0.1 to $1.5^{\mathrm{b}}$ & $>1.5^{b}$ & 5 \\
\hline $\mathrm{Mn}$ & $\mathrm{mg} \mathrm{L}^{-1}$ & 0.1 & $<0.1^{\mathrm{b}}$ & 0.1 to $1.5^{b}$ & $>1.5^{b}$ & 0.2 \\
\hline $\mathrm{Cu}$ & $\mathrm{mg} \mathrm{L}^{-1}$ & 0.01 & & & & 0.2 \\
\hline $\mathrm{B}$ & $\mathrm{mg} \mathrm{L}^{-1}$ & 0.2 & $<0.7$ & 0.7 to 3 & $>3$ & - \\
\hline EC & $\mathrm{dS} / \mathrm{M}$ & 1.1 & $<0.7$ & 0.7 to 3 & $>3$ & - \\
\hline SAR & $\left(\left[\text { melq L }^{-1}\right]^{1 / 2}\right)$ & 5.3 & $>1.2 \mathrm{EC}^{\mathrm{e}}$ & $1.2 \mathrm{~A} 0.3 \mathrm{EC}^{\mathrm{e}}$ & $<0.3 \mathrm{EC}^{\mathrm{e}}$ & - \\
\hline \multirow{2}{*}{$\mathrm{Na}$} & \multirow{2}{*}{$\mathrm{mg} \mathrm{L}^{-1}$} & \multirow{2}{*}{150.8} & $<69^{c}$ & $>69^{c}$ & - & - \\
\hline & & & $<69^{d}$ & 69 to $207^{d}$ & $>207^{d}$ & - \\
\hline
\end{tabular}

TW - Treated wastewater; EC - electrical conductivity; SAR - sodium adsorption ratio; a - (WHO, 2006); b, c, and d - restriction values for drip, sprinkler and surface irrigation methods, respectively; and - e the degrees of restriction for SAR are determined according to the EC.

Table 2: Physical and chemical characteristics of the soils used in the experiment.

\begin{tabular}{|c|c|c|c|c|c|c|c|c|c|c|c|c|c|}
\hline & $\mathrm{pH}$ & OM & $\mathrm{P}$ & K & $\mathrm{Ca}$ & $\mathrm{Mg}$ & $\mathrm{Al}$ & $\mathrm{H}+\mathrm{Al}$ & CEC & V & Sand & Silt & Clay \\
\hline & in $\mathrm{H}_{2} \mathrm{O}$ & $\mathrm{g} \mathrm{kg}^{-1}$ & \multicolumn{2}{|c|}{$\mathrm{mg} \mathrm{dm} \mathrm{m}^{-3}$} & \multicolumn{5}{|c|}{$\mathrm{cmolc} \mathrm{dm}^{-3}$} & \multicolumn{4}{|c|}{$\%$} \\
\hline \multicolumn{14}{|c|}{ Before the experiment } \\
\hline CS & 5.7 & 6.01 & 6.42 & 106 & 5.20 & 1.15 & 0 & 3.17 & 9.79 & 68 & 20 & 40 & 40 \\
\hline SLS & 5.3 & 3.88 & 1.99 & 10 & 0.47 & 0.25 & 0.3 & 2.45 & 3.20 & 23 & 78 & 10 & 12 \\
\hline \multicolumn{14}{|c|}{ After the experiment } \\
\hline CS & 5.7 & 4.71 & 5.51 & 47.41 & 4.57 & 0.72 & 0.00 & 1.61 & 6.99 & 77.50 & 20 & 40 & 40 \\
\hline SLS & 5.6 & 2.74 & 1.35 & 13.17 & 0.52 & 0.19 & 0.15 & 1.37 & 2.15 & 35.95 & 78 & 10 & 12 \\
\hline
\end{tabular}

CS - Clay Soil; SLS - Sandy Loam Soil; pH in distilled water; P and K, Mehlich-1 extractor; OM - Organic Matter; V - Base Saturation; CEC - Cation Exchange Capacity; $\mathrm{H}+\mathrm{Al}$ - potential acidity.

The experiment was conducted in a greenhouse protected from rain with internal temperature ranging from 13 to $34{ }^{\circ} \mathrm{C}$. Pots of $14 \mathrm{~L}$, sealed in the bottom to avoid water drainage, were filled with $11 \mathrm{~kg}$ of soil. Urea, simple superphosphate, and potassium chloride were applied to provide $250 \mathrm{mg}$ of nitrogen $(\mathrm{N}), 350$ $\mathrm{mg}$ of phosphorus $(\mathrm{P})$, and $300 \mathrm{mg}$ of potassium $(\mathrm{K})$ per pot, which is equivalent to $50 \mathrm{~kg}$ of $\mathrm{N}, 70 \mathrm{~kg}$ of $\mathrm{P}_{2} \mathrm{O}_{5}$ and $60 \mathrm{~kg}$ of $\mathrm{K}_{2} \mathrm{O}$ ha $^{-1}$ (Ribeiro; Guimarães; Alvarez, 1999). These fertilizers were previously incorporated into the soils used in the experiment, aiming to provide initial nutritional conditions for millet growth and development according to crop fertilization recommendations and works with similar methodology (Dube et al., 2018; Ijaz et al., 2019; Ribeiro; Guimarães; Alvarez, 1999; Tunc; Sahin, 2017). 
When planting millet (Pennisetum glaucum), ten seeds were planted per pot, and thinning was performed at ten days after emergence (DAE), preserving two plants per pot. Weeds were removed manually as the experiment was carried out.

Treatments corresponding to the five dilution levels of TW $(0,25,50,75$, and $100 \%)$ were applied via irrigation at 10 DAE. Previously, the pots were irrigated using only distilled water. To obtain the proper irrigation depth, 10 pots identical to those used in the experiment were planted under the same condition in parallel, but with a drainage system in the bottom, so that each pot received one of the ten treatments. This constituted a lysimeter system. The irrigation depth applied to the experimental plots (bottomsealed pots) was determined by the volume of water used in the lysimeters subtracted from the average volume of water drained by the lysimeters.

At $66 \mathrm{DAE}$, gas exchange measurements were carried out using an ADC infrared gas analyzer (IRGA), Model LCA 4 (Analytical Development Co. Ltd, Hoddesdon, United Kingdom). In this evaluation, a fully expanded and apparently healthy leaf located in the upper third of the plant was selected and subjected to a constant light source of $1.200 \mathrm{mmol} \mathrm{m}^{-2} \mathrm{~s}^{-1}$ photons. For more homogeneous environmental conditions and more accurate data interpretation, the gas exchange measurements were performed between 8:00 and 11:00 a.m. The parameters of the gas exchange measurements were: net photosynthesis $\left(\mathrm{Pn}-\mu \mathrm{mol}\right.$ of $\left.\mathrm{CO}_{2} \mathrm{~m}^{-2} \mathrm{~s}^{-1}\right)$, stomatal conductance of water vapor $\left(\mathrm{G}_{\mathrm{s}}\right.$ of $\left.\mathrm{H}_{2} \mathrm{O} \mathrm{mol} \mathrm{m} \mathrm{m}^{-2} \mathrm{~s}^{-1}\right)$ and transpiration rate $(\mathrm{E}$ mmol of $\left.\mathrm{H}_{2} \mathrm{O} \mathrm{m}^{-2} \mathrm{~s}^{-1}\right)$. Moreover, instantaneous water use efficiency (iWUE - mol of $\mathrm{CO}_{2}$ mol of $\mathrm{H}_{2} \mathrm{O}^{-1}$ ) was calculated based on the ratio between net photosynthesis and transpiration rate $(\mathrm{Pn} / \mathrm{E})$.

The contents of total chlorophyll and chlorophyll $a$ and $b$ were determined at 66 DAE, using a chlorophyll meter (ClorofiLOG, model CFL 1030, FALKER, Porto Alegre, Brazil), operated according to the manufacturer's specifications. In the measurements, the fourth fully expanded leaf from the top to the base of the stem was used.

To determine the levels of macro- and micronutrients, the fourth leaf fully expanded from the apex to the base of the stem of all plants of each plot (two plants) was collected at 66 DAE. The materials were taken to the laboratory, dried in a forced circulation greenhouse at $65^{\circ} \mathrm{C}$ until constant weight was obtained, ground in a Willey mill and sieved ( $2 \mathrm{~mm}$ sieve) for further extraction by nitric-perchloric digestion $(\mathrm{P}, \mathrm{K}, \mathrm{Ca}, \mathrm{Mg}, \mathrm{S}, \mathrm{Cu}, \mathrm{Fe}, \mathrm{Mn}$, and $\mathrm{Zn}$ ), sulfuric digestion (N) and muffle calcination (B), as described by (Silva, 2009).
The data were subjected to variance analysis using the F-test at the level of 5\% probability of error, and in cases of significance, regression analysis was performed for the levels of TW concentration, through the 'ExpDes. $p t$ ' package implemented in $\mathrm{R}$ software, version 3.4.2 ( $\mathrm{R}$ Development Core Team, 2017).

\section{RESULTS AND DISCUSSION}

Increased TW concentration in the irrigation water caused a significant linear increase $(p \leq 0.05)$ in net photosynthesis (Pn) and stomatal conductance (Gs). The millet plants irrigated with $100 \%$ TW showed Pn and Gs about 50 and $34 \%$ higher, respectively, than the control plants (without TW) (Figure 1A and C). The effects of the interaction between soil type and TW concentration on the irrigation water were significant $(p \leq 0.05)$ only for transpiration rate (E). For sandy loam soil, a linear increase in $\mathrm{E}$ was observed as the concentration of TW in the irrigation water increased. Under this condition, the millet plants irrigated with $100 \%$ TW showed an increase of $52 \%$ in E, when compared with the control treatment (without TW). Regarding clay soil, the millet plants showed maximum E $\left(3.74 \mathrm{mmol}\right.$ of $\left.\mathrm{H}_{2} 0 \mathrm{~m}^{-2} \mathrm{~s}^{-1}\right)$ when irrigated with $78 \%$ TW (Figure 1E). The plants grown in clay soil showed higher E than in sandy soil, regardless of the concentration of TW in the irrigation water (Figure 1e). Higher Pn, Gs and instantaneous water use efficiency were also observed (iWUE) in plants grown in clay soil, with increase rates of 56, 14, and $18 \%$, respectively (Figures $1 \mathrm{~B}, \mathrm{D}$, and F).

The effects of the interaction between soil type and TW concentration in the irrigation water were significant $(\mathrm{p} \leq 0.05)$ in all chlorophyll parameters (total chlorophyll, chlorophyll $a, b$, and $a / b$ ). The increased concentration of TW in the irrigation water produced a significant difference $(p \leq 0.05)$ in the content of total chlorophyll in clay and sandy loam soils, and of chlorophyll $b$ and $a / b$ in the sandy loam soil (Figure 2). For the clay soil, a linear increase in the content of total chlorophyll and chlorophyll $a$ was observed due to the increase in the concentration of TW in the irrigation water. The millet plants irrigated with $100 \%$ TW in clay soil showed an increase in total chlorophyll and chlorophyll $a$ of 26 and $21 \%$, respectively, when compared with the control treatment (without TW) (Figure 2A and B). For the sandy loam soil, an increase in total chlorophyll and chlorophyll $a$ and $b$ was observed as the concentration of TW in the irrigation water increased, and millet plants irrigated with $100 \%$ TW showed an increase of 131, 105 and $425 \%$ in total chlorophyll and chlorophyll $a$ and $b$, respectively, when compared with the control treatment 
(without TW) (Figure 2A, B, and C). Plants grown in clay soil had a higher content of total chlorophyll and chlorophyll $a$ and $b$ and a lower chlorophyll $a / b$ ratio than in sandy loam soil when irrigated with TW concentrations lower than $67,55,58$ and $54 \%$, respectively (Figure 2). The values of the chlorophyll $a / b$ ratio in the leaves decreased as the concentrations of TW increased. The highest value found was 7.78 and the lowest was 3.39, relative to 0 and $75 \% \mathrm{TW}$, respectively (Figure 2D).

The effects of the interaction between soil type and TW concentration in the irrigation water were significant $(\mathrm{p} \leq 0.05)$ for the accumulation of all macroand micronutrients $(\mathrm{N}, \mathrm{P}, \mathrm{K}, \mathrm{Ca}, \mathrm{Mg}, \mathrm{S}, \mathrm{Zn}, \mathrm{Fe}, \mathrm{Mn}, \mathrm{Cu}$, and $\mathrm{B}$ ) and of $\mathrm{Na}$ in millet leaves (Figure 3 ). The increased concentration of TW in the irrigation water increased the accumulation of nutrients and $\mathrm{Na}$ in millet leaves grown in both soils, except for $\mathrm{P}$ and $\mathrm{Cu}$ in sandy loam soil, in which the accumulation of these nutrients did not differ significantly ( $p>0.05)$ due to increased TW concentration. Plants grown in clay soil showed greater absorption of nutrients and $\mathrm{Na}$, when compared with those of the treatments in sandy loam soil.
A.

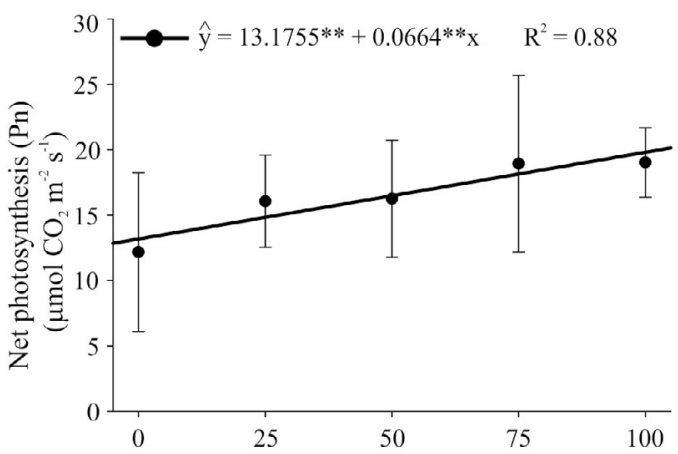

C.

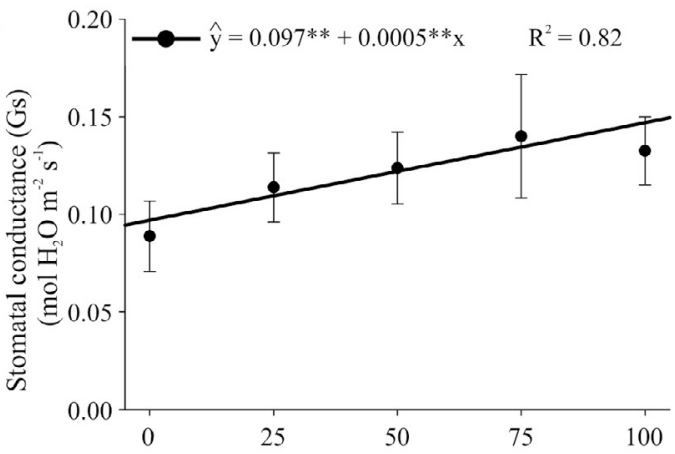

E.

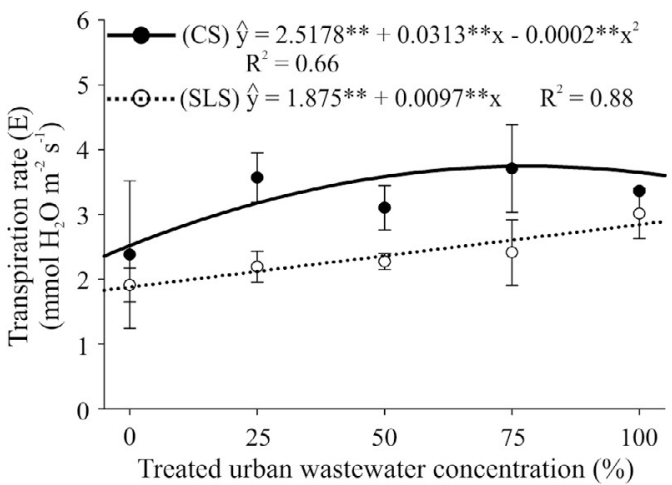

B.

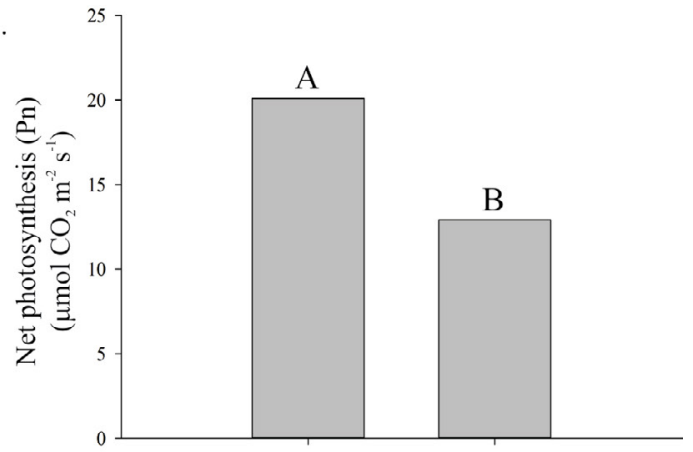

D.

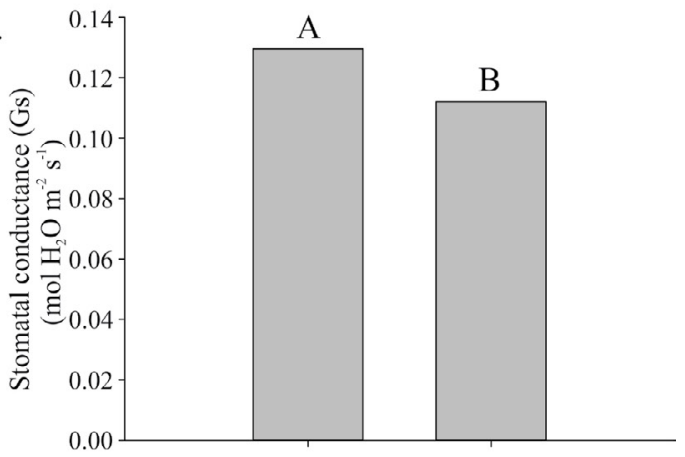

F.

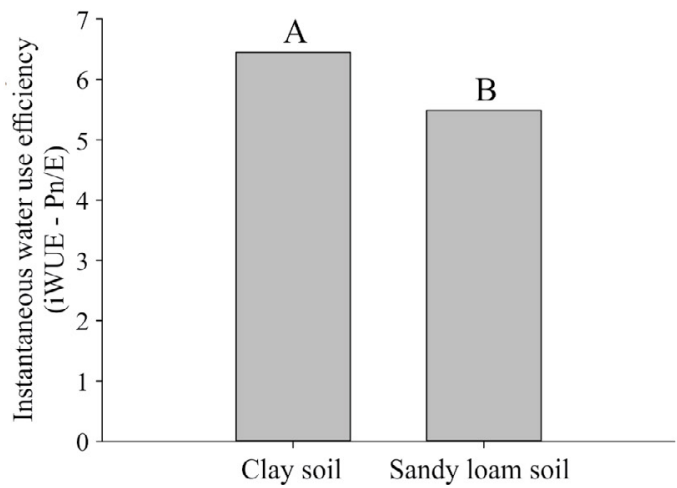

Figure 1: Effect of the concentrations of treated wastewater (TW) applied to clay soil (CS) and sandy loam soil $(S L S)$ on net photosynthesis $(P n,(A, B))$, stomatal conductance $(G s,(C, D))$, transpiration rate $(E,(E))$ and instant water use efficiency (iWUE, (F)) of millet plants. 

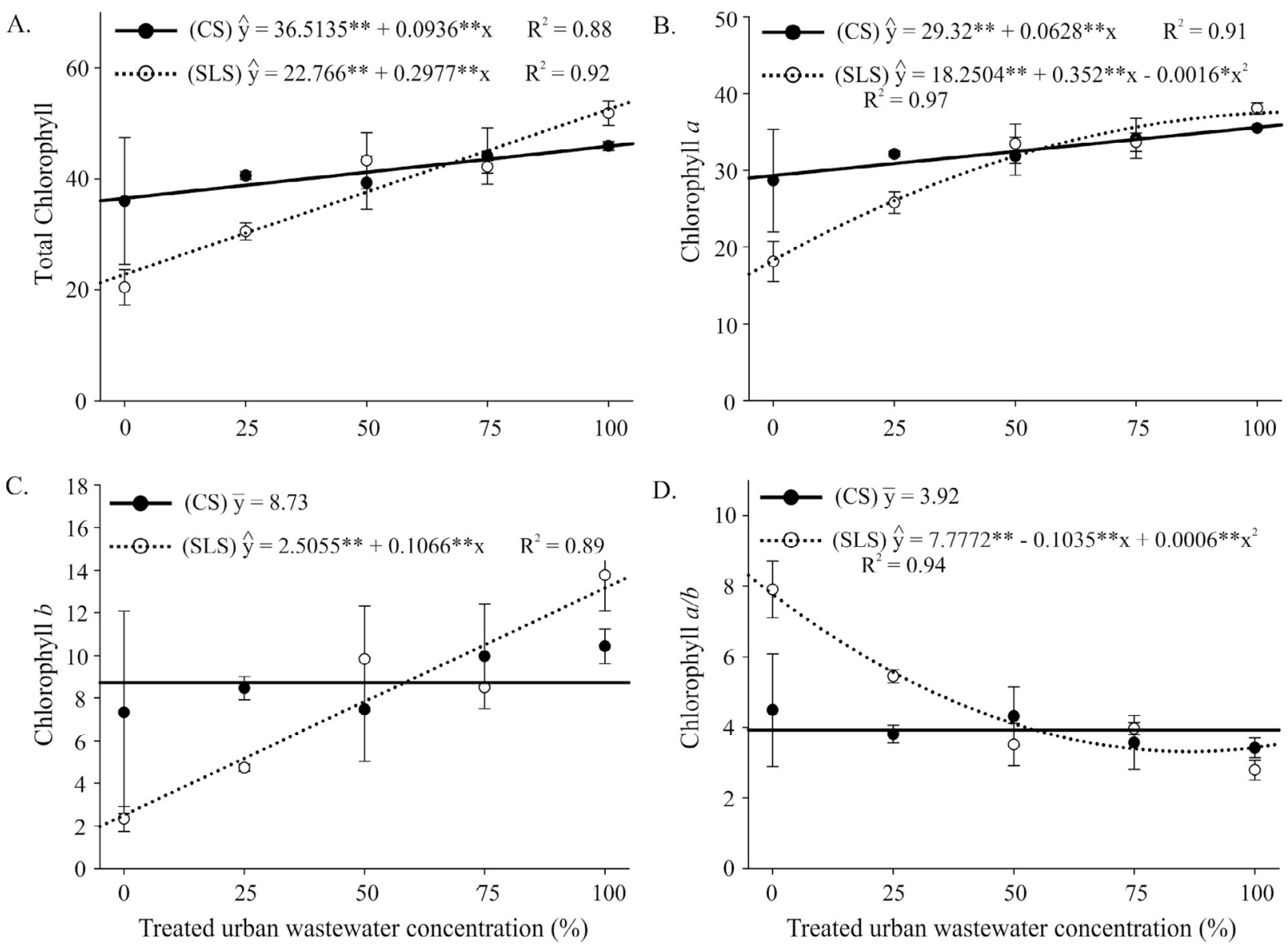

Figure 2: Effect of treated wastewater (TW) concentrations applied to clay soil (CS) and sandy loam soil (SLS) on the content of total chlorophyll (A), chlorophyll $a(\mathrm{~B})$, chlorophyll $b(\mathrm{C})$ and chlorophyll $a / b(\mathrm{D})$ in millet leaves.

Increase in the concentration of TW in the irrigation water increased the gas exchange variables $(\mathrm{Pn}$, Gs and E), especially in treatments with 75 and $100 \%$ TW (Figure 1). The TW contained considerable amounts of nutrients (Table 1) considered essential for photosynthetic activity, stomatal regulation and chlorophyll synthesis of the plants (Ben Hassena et al., 2018; Taiz; Zeiger, 2013; Tekaya et al., 2016). In the literature, the use of wastewater in irrigation is associated with increased photosynthetic performance and transpiration of plants (Ben Hassena et al., 2018; Corbel et al., 2016; Iqbal et al., 2015). This increase is usually related to the fact that wastewater is a rich source of nutrients and organic matter (Aman et al., 2018; Iqbal et al., 2015; Monnett; Reneau Jr; Hagedorn, 1996).

Plants irrigated with TW may present variable responses due to the availability of nutrients and salts in wastewater, plant species and irrigation period (Ben Hassena et al., 2018; Khawla et al., 2019). In this study, the increase in $\mathrm{Pn}$, Gs and $\mathrm{E}$ due to increasedconcentration of TW in the irrigation water may be related to a greater accumulation of nutrients in millet leaves (Figure 3 ).

Increase in the content of total chlorophyll and chlorophyll $a$ and $b$ in sandy loam soil due to increased concentration of TW in the irrigation water (Figure 2) may be related to photosynthetic behavior (Figure 1) and accumulation of $\mathrm{N}$ and $\mathrm{Mg}$ in millet leaves (Figure 3), chemical elements related to chlorophyll synthesis in plants (Taiz; Zeiger, 2013). Comparatively, these results are similar to those reported by Helaly et al. (2018) and Ben Hassena et al. (2018), who observed that wastewater irrigation positively influenced the content of total chlorophyll in mango trees (Mangifera indica L.) and olive trees (Olea europaea L. cv. Chetoui), respectively. Increase in salinity increases the availability of $\mathrm{Na}^{+}$ in the soil, which negatively influences the chlorophyll synthesis, by inducing the activity of chlorophyllase, an 
enzyme that promotes chlorophyll degradation (Sevengor et al., 2011). Thus, the results of this study related to sandy loam soil showed that the concentration of $\mathrm{Na}^{+}$ on the leaves was not enough to cause photochemical damage. However, in clay soil, the lowest mean values of total chlorophyll and chlorophyll $a$ and $b$ in millet plants irrigated with 75 and $100 \% \mathrm{TW}$, when compared with plants in sandy loam soil (Figure 2A, B, and C), may be associated with higher $\mathrm{Na}$ accumulation in millet plants in clay soil (Figure 3L) in response to soil salinization. The increased concentration of TW in the irrigation water did not cause a significant difference $(p>0.05)$ in chlorophyll $b$ (Figure 2c), although the accumulation of $\mathrm{N}$ and $\mathrm{Mg}$ increased in millet leaves grown in clay soil (Figure 3A and E), which may also be associated with increased accumulation of $\mathrm{Na}$ in millet plants (Figure 3L).
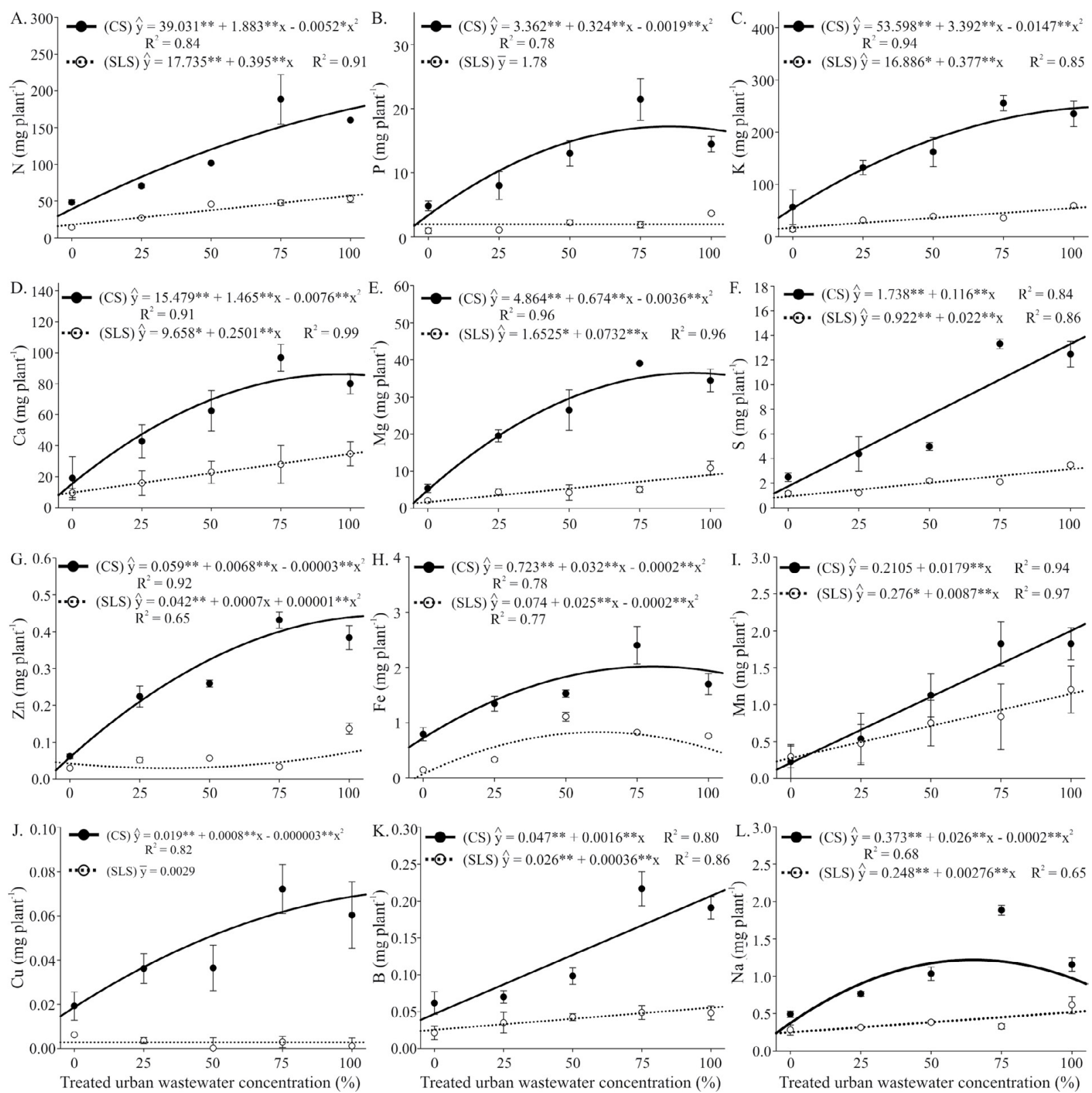

Figure 3: Effect of the concentrations of treated wastewater (TW) applied to clay soil (CS) and sandy loam soil (SLS) on the accumulation of $N(A), P(B), K(C), C a(D), M g(E), S(F), Z n(G), F e(H), M n(I), C u(J)$, and $B(K)$ in millet leaves. 
Increased concentration of TW in the irrigation water favored the photosynthetic activity of millet plants. The significant increase $(\mathrm{P} \leq 0.05)$ in Pn (Figure 1A) and the reduction in the chlorophyll $a / b$ ratio (Figure 2D) justify this finding. According to (Cancellier et al., 2011), the drop in this ratio, is justified by the higher levels of chlorophyll $b$ in the leaves, thus increasing the efficacy of the photosynthetic reactions. Chlorophyll $a$ actively participates in the first photochemical process of photosynthesis, while the main function of chlorophyll $b$ is absorption of light in the wavelength spectrum not absorbable by chlorophyll $a$ (Taiz; Zeiger, 2013).

Increase in the accumulation of macro- and micronutrients in millet leaves, due to increased concentration of TW in the irrigation water, can be explained by the presence of these ions in TW (Table 1). The results observed in this study corroborate those by Aman et al. (2018), Ben Hassena et al. (2018), Corbel et al. (2016), Dube et al. (2018) and Yaseen et al. (2017), who observed increased accumulation of macro- and micronutrients in plants due to higher wastewater concentration in the irrigation water. The use of wastewater in agricultural irrigation is also associated with improvements in the physicochemical characteristics of soils, such as increase in soil organic matter content and in cation (Iqbal et al., 2015; Monnett; Reneau Jr; Hagedorn, 1996) exchange capacity, which may also have favored the greater accumulation of nutrients in millet leaves irrigated with the highest TW concentrations (Figure 3).

Increased concentration of TW in the irrigation water caused a quadratic-linear behavior in the accumulation of nutrients in millet leaves, except for $\mathrm{S}, \mathrm{Mn}$, and $\mathrm{B}$, and the millet plants showed the highest values of nutrients accumulation when irrigated with TW concentrations between 75 and $100 \%$ (Figure 3). Increase in TW concentration favored soil salinization (Figure 3L), which may explain the quadratic behavior observed in clay soil. The use of untreated or improperly treated wastewater in agricultural irrigation may impair plant growth and development and the absorption of nutrients due to possible soil salinization and contamination of plants and soil with pathogens, heavy metals or other toxic elements (Bedbabis et al., 2015; Chen et al., 2016; Demir; Sahin, 2017; Obayomi et al., 2019; Sou-Dakouré et al., 2013). In sandy loam soil, increased concentration of TW in the irrigation water caused a linear increase in the the accumulation of all nutrients, except for $\mathrm{P}, \mathrm{Fe}$, and $\mathrm{Cu}$. This result shows that, contrary to what was observed for clay soil, irrigation with $100 \%$ TW does not affect the accumulation of nutrients in millet plants grown in sandy loam soil for a short period (Figure 3), despite the increase in the availability of $\mathrm{Na}$ (Table 1 and Figure 3L).

The results of this study show that millet plants cultivated in clay soil presented higher Pn, Gs, E, iWUE (Figure 1B, 1D, 1E, and $1 \mathrm{~F}$ ) and accumulation of macro- and micronutrients (Figure 3), when compared with sandy loam soil. Soil texture and structure affect soil nutrient retention capacity, aeration, water retention capacity and drainage (Brady; Weil, 2013; Panta et al., 2016; Warrence; Bauder; Pearson, 2002), which justifies the influence of soil type on the performance of millet plants. In addition, millet plants may have benefited from the nutrient content $(\mathrm{P}, \mathrm{K}, \mathrm{Ca}$, and $\mathrm{Mg}$ ), organic matter, base saturation and naturally high capacity of clay soil to exchange cations (Table 2). Comparatively, these results are similar to those reported by Panta et al. (2016) and Dube et al. (2018). These results show that soil texture and structure may play a significant role in the growth and development of millet plants irrigated with TW.

\section{CONCLUSIONS}

Irrigation of clay soil and sandy loam soil with increasing concentrations of treated wastewater increases gas exchange capacity and nutrient accumulation in millet plants, and the most suitable concentrations for use in clay soil and sandy loam soil are 75 and 100\% treated wastewater, respectively. Cultivation in clay soil contributes to the increase in gas exchange capacity and nutrient accumulation in millet, when compared with cultivation in sandy loam soil. Treated wastewater can be used as a good nutrient source for millet plants due to its considerable amounts of essential nutrients. Thus, treated wastewater can be applied to the growth cycle of millet to reduce the demand for fresh water and the use of chemical fertilizers.

\section{ACKNOWLEDGEMENTS}

The authors thank Conselho Nacional de Desenvolvimento Científico e Tecnológico (CNPq) for providing scholarships and financial support; and Espaço da Escrita - Pró-Reitoria de Pesquisa - UNICAMP - for the language services provided.

\section{REFERENCES}

ALI-SHTAYEH, M. S. et al. Secondary treated effluent irrigation did not impact chemical composition, and enzyme inhibition activities of essential oils from Origanum syriacum var. syriacum. Industrial Crops and Products, 111:775-786, 2018. 
AMAN, M. S. et al. Assessing the effect of industrial wastewater on soil properties and physiological and nutritional responses of Robinia pseudoacacia, Cercis siliquastrum and Caesalpinia gilliesii seedlings. Journal of Environmental Management, 217:718-726, 2018.

APHA. Standard Methods for the Examination of Water and Waste Water. Washington, D.C.: APHA (American Public Health Association), 2012. 1496p.

AYERS, R. S.; WESTCOT, D. W. Water quality for agriculture. Rome: FAO 29, 1999. 218p.

BEDBABIS, S. et al. Long-terms effects of irrigation with treated municipal wastewater on soil, yield and olive oil quality. Agricultural Water Management, 160:14-21, 2015.

BEN HASSENA, A. et al. Physiological improvements of young olive tree (Olea europaea L. cv. Chetoui) under short term irrigation with treated wastewater. Agricultural Water Management, 207:53-58, 2018.

BERNSTEIN, N. Potential for contamination of crops by microbial human pathogens introduced into the soil by irrigation with treated effluent. Israel Journal of Plant Sciences, 59(2-4):115-123, 2011.

BRADY, N. C.; WEIL, R. R. Elementos da natureza e propriedades dos solos. Porto Alegre: Bookman, 2013. 716p.

CANCELLIER, E. L. et al. Eficiência agronômica no uso de nitrogênio mineral por cultivares de arroz de terras altas. Revista Brasileira de Ciências Agrárias, 6(4):650-656, 2011.

CHEN, A. et al. Influence of long-term irrigation with treated papermaking wastewater on soil ecosystem of a full-scale managed reed wetland. Journal of Soils and Sediments, 16(4):1352-1359, 2016.

CORBEL, S. et al. Effects of repeated soil irrigation with liquid biological paper sludge on poplar Populus alba saplings: Potential risks and benefits. Environmental Science and Pollution Research, 23(21):21584-21593, 2016.

DEMIR, A. D.; SAHIN, U. Effects of different irrigation practices using treated wastewater on tomato yields, quality, water productivity, and soil and fruit mineral contents. Environmental Science and Pollution Research, 24(32):24856-24879, 2017.

DUBE, S. et al. Effects of sludge water from a water treatment works on soil properties and the yield and elemental uptake of Brachiaria decumbens and lucerne (Medicago sativa). Agricultural Water Management, 208:335-343, 2018.
DUDHATE, A. et al. Transcriptomic analysis reveals the differentially expressed genes and pathways involved in drought tolerance in pearl millet [Pennisetum glaucum (L.) R. Br]. PLoS ONE, 13(4):e0195908, 2018. Available in: <https://journals.plos.org/plosone/article?id=10.1371/ journal.pone.0195908>. Access in: April, 10, 2019.

EMPRESA BRASILEIRA DE PESQUISA AGROPECUÁRIA EMBRAPA. Sistema brasileiro de classificação de solos. Brasília: Embrapa, 2013. 353p.

FARAHAT, E.; LINDERHOLM, H. W. The effect of long-term wastewater irrigation on accumulation and transfer of heavy metals in Cupressus sempervirens leaves and adjacent soils. Science of the Total Environment, 512-513:1-7, 2015.

HANJRA, M. A. et al. Wastewater irrigation and environmental health: Implications for water governance and public policy. International Journal of Hygiene and Environmental Health, 215(3):255-269, 2012.

HELALY, M. N. et al. Impact of treated wastewater and salicylic acid on physiological performance, malformation and yield of two mango cultivars. Scientia Horticulturae, 233:159-177, 2018.

IQBAL, S. et al. Comparative effect of wastewater and groundwater irrigation along with nitrogenous fertilizer on growth, photosynthesis and productivity of chilli (Capsicum annuum L.). Journal of Plant Nutrition, 38(7):1006-1021, 2015.

IJAZ, M. et al. Sewage waste water application improves the productivity of diverse wheat (Triticum aestivum L.) cultivars on a sandy loam soil. Environmental Science and Pollution Research, 26(17):17045-17054, 2019.

JUKANTI, A. K. et al. Crops that feed the world 11. Pearl Millet (Pennisetum glaucum L.): An important source of food security, nutrition and health in the arid and semi-arid tropics. Food Security, 8(2):307-329, 2016.

KALAVROUZIOTIS, I. K. et al. Effects of municipal reclaimed wastewater on the macro- and micro-elements status of soil and of Brassica oleracea var. Italica, and B. oleracea var. Gemmifera. Agricultural Water Management, 95(4):419426, 2008.

KHAWLA, K. et al. Accumulation of trace elements by corn (Zea mays) under irrigation with treated wastewater using different irrigation methods. Ecotoxicology and Environmental Safety, 170:530-537, 2019.

MALASH, N.; FLOWERS, T. J.; RAGAB, R. Effect of irrigation systems and water management practices using saline and non-saline water on tomato production. Agricultural Water Management, 78(1-2):25-38, 2005. 
MENG, W. et al. Heavy metals in soil and plants after long-term sewage irrigation at Tianjin China: A case study assessment. Agricultural Water Management, 171:153-161, 2016.

MONNETT, G. T.; RENEAU, R. B.; HAGEDORN, C. Evaluation of spray irrigation for on-site wastewater treatment and disposal on marginal soils. Water and Environmental Research, 68(1):11-18, 1996.

OBAYOMI, O. et al. The fate of pathogens in treated wastewatersoil-crops continuum and the effect of physical barriers. Science of the Total Environment, 681:339-349, 2019.

PANTA, S. et al. Growth responses of Atriplex lentiformis and Medicago arborea in three soil types treated with saline water irrigation. Environmental and Experimental Botany, 128:39-50, 2016.

PAUDEL, I. et al. Reductions in root hydraulic conductivity in response to clay soil and treated waste water are related to PIPs down-regulation in Citrus. Scientific Reports, 7(15429)1-14, 2017.

PAUDEL, I. et al. Impact of treated wastewater on growth, respiration and hydraulic conductivity of citrus root systems in light and heavy soils. Tree Physiology, 36(6):770-785, 2016.

R DEVELOPMENT CORE TEAM. R: A language and environment for statistical computing, reference index version 3.4.2. Vienna, Austria: R foundation for statistical computing, 2017. Available in: <https://cran.r-project.org/bin/windows/ base/old/3.4.2/>. Access in: November, 10, 2018.

RIBEIRO, A. C.; GUIMARÃES, P. T. G.; ALVAREZ V, V. H. Recomendação para o uso de corretivos e fertilizantes em Minas Gerais. Viçosa: CFSEMG/UFV, 1999. 359p.

SEVENGOR, S. et al. The effect of salt stress on growth, chlorophyll content, lipid peroxidation and antioxidative enzymes of pumpkin seedling. African Journal of Agricultural Research, 6(21):4920-4924, 2011.

SILVA, F. C. Manual de análises químicas de solos, plantas e fertilizantes. Brasília: Embrapa Informação Tecnológica, 2009. 627p.
SOU-DAKOURÉ, M. Y. et al. Impacts of irrigation with industrial treated wastewater on soil properties. Geoderma, 200201:31-39, 2013.

TAIZ, L.; ZEIGER, E. Fisiologia Vegetal. 5. ed. Porto Alegre: Artmed, 2013. 918p.

TEKAYA, M. et al. Changes in key photosynthetic parameters of olive trees following soil tillage and wastewater irrigation, modified olive oil quality. Agricultural Water Management, 178:180-188, 2016.

THELUSMOND, J. R.; STRATHMANN, T. J.; CUPPLES, A. M. Carbamazepine, triclocarban and triclosan biodegradation and the phylotypes and functional genes associated with xenobiotic degradation in four agricultural soils. Science of the Total Environment, 657:1138-1149, 2019.

TUNC, T.; SAHIN, U. Yield and heavy metal content of wastewater-irrigated cauliflower and soil chemical properties. Communications in Soil Science and Plant Analysis, 48(10):1194-1211, 2017.

WARRENCE, N. J.; BAUDER, J. W.; PEARSON, K. E. Basics of salinity and sodicity effect on soil physical propertiese. M. S. U. Department of Land Resources and Environmental Sciences: Montana State University, Bozeman, 2002. 29p.

WHO. WHO guidelines for the safe use of wastewater, excreta and greywater. Geneva: World Health Organisation. 2006. 196p.

YASEEN, M. et al. Management of textile wastewater for improving growth and yield of field mustard (Brassica campestris L.). International Journal of Phytoremediation, 19(9):798-804, 2017.

YU, Y. et al. The effects of treated wastewater irrigation on soil health. Advanced Materials Research, 393-395:15451549, 2012.

ZHANG, Y. et al. Effects of soil texture and drought stress on the uptake of antibiotics and the internalization of Salmonella in lettuce following wastewater irrigation. Environmental Pollution, 208(Part B):523-531, 2016. 